Volume I, No 1, Februari 2017

Hal 111-125

\title{
KEBERLANJUTAN PERIKANAN TUNA DI PERAIRAN SENDANGBIRU KABUPATEN MALANG
}

\author{
Sustainability of Tuna Fisheries in Sendangbiru Malang District \\ Oleh: \\ Made Mahendra Jaya $^{1 *}$, Budy Wiryawan², dan Domu Simbolon² \\ ${ }^{1}$ Mahasiswa Program Pascasarjana Departemen PSP FPIK IPB \\ ${ }^{2}$ Departemen PSP FPIK IPB \\ *Korespondensi: mademahendrajaya@gmail.com
}

\begin{abstract}
ABSTRAK
Ikan tuna memiliki nilai ekonomis penting dan tersebar hampir di seluruh wilayah di perairan Indonesia. Kegiatan pemanfaatan sumberdaya tuna telah memberikan kontribusi yang besar bagi sektor perikanan di Indonesia. Kebutuhan dan tingginya permintaan pasar terhadap ikan tuna menyebabkan intensitas penangkapan ikan ini semakin meningkat. Peningkatan intensitas penangkapan ikan tuna terjadi di seluruh wilayah perairan Indonesia. Tingginya intensitas penangkapan ikan tuna khususnya di daerah Selatan Jawa dikhawatirkan akan mengancam kelestarian dan keberlanjutan pemanfaatan sumberdaya ikan tuna. Daerah Sendangbiru di Kabupaten Malang merupakan salah satu daerah penghasil tuna terbesar di Jawa Timur. Peningkatan intensitas penangkapan ikan tuna di daerah ini juga terjadi setiap tahunnya. Analisis keberlanjutan dari kegiatan perikanan tuna sangat perlu dilakukan untuk mengetahui keadaan terkini dari perikanan tuna di daerah Sendangbiru. Penelitian ini bertujuan untuk menentukan tingkat keberlanjutan dari masing-masing domain atau aspek yang ada di dalam EAFM dan menentukan tingkat keberlanjutan kegiatan perikanan tuna di perairan Sendangbiru. Metode yang digunakan dalam penelitian ini adalah dengan pendekatan berbasis ekosistem (Ecosystem Approach to Fisheries Management / EAFM). Hasil dari penelitian ini menunjukan aspek yang memiliki tingkat keberlanjutan sangat baik meliputi aspek teknik penangkapan ikan, ekonomi dan kelembagaan, sedangkan domain/aspek yang memiliki tingkat keberlanjutan sedang meliputi sumberdaya ikan, habitat dan ekosistem perairan dan sosial. Tingkat keberlanjutan kegiatan perikanan tuna di daerah Sendangbiru tergolong baik. Perolehan nilai dari analisis komposit dari setiap domain dalam indikator EAFM sebesar 80.28.
\end{abstract}

Kata kunci: keberlanjutan, perikanan tuna, EAFM

\begin{abstract}
Tuna has an important economic value and it spread to almost all regions in Indonesian water. Tuna resource utilization activity has made a great contribution for fisheries sector in Indonesia. High market demand and needs for tuna lead the increasing of tuna fishing intensity. It occurred in all Indonesian water. High intensity of tuna fishing especially in the Southern regions of Java is feared to threaten the preservation and sustainable of tuna resource. Sendangbiru region in Malang district is one of the largest tuna producer in East Java. The increasing of the tuna fishing intensity in this area also occur annually. The sustainability analysis of tuna fishing activity is very necessary to know the current state of the tuna fisheries in this area. This reaserch aims to determine the level of sustainability of each domain in EAFM and to determining the sustainability level of tuna fishing activities. The methods used in this study are ecosystem approach (Ecosystem Approach to Fisheries Management EAFM). The result of this study showed the aspects that have a very good level og sustainability are fishing techniques, economic and institution, and which have a moderate level are fish resources,
\end{abstract}


habitat and social. The sustainability level of tuna fishing activities in Sendangbiru is good. This result was obtained by using EAFM. The acquisition value of composite analysis from each domain in EAFM indicators amounted to 80.28 .

Keywords: sustainability, tuna fisheries, EAFM

\section{PENDAHULUAN}

Sumberdaya ikan tuna memiliki nilai ekonomis penting dan tersebar hampir di seluruh wilayah di perairan Indonesia. Nilai ekonomis yang dimiliki ikan tuna menjadikannya sebagai salah satu komuditi utama dari subsektor perikanan nasional baik untuk konsumsi maupun komoditi ekspor. Meningkatnya permintaan pasar terhadap produk dari ikan tuna menjadi peluang bagi perikanan Indonesia. Menurut Sumadhiharga (2009) perikanan tuna memberikan kontribusi yang cukup besar bagi perekonomian bangsa Indonesia, khususnya dalam hal perolehan devisa negara dan masih mempunyai peluang untuk terus dikembangkan. Semakin meningkatnya permintaan pasar terhadap ikan tuna maka tekanan terhadap penangkapan ikan tuna akan semakin meningkat. Tingginya tekanan terhadap perikanan tuna dikhawatirkan akan mengganggu sumberdaya ikan tuna itu sendiri. Diperlukan suatu pengelolaan perikanan tuna untuk menjamin keberlanjutan perikanan tuna. Tanpa adanya pengelolaan yang baik akan dikhawatirkan terjadinya penurunan sumberdaya ikan tuna dan mengancam kelestarian perikanan tuna di Indonesia.

Pengelolaan kegiatan perikanan merupakan suatu kewajiban agar tercapai pengelolaan perikanan yang berkelanjutan. Diharapkan semua wilayah perairan Indonesia dapat mengatur pengelolaan perikanan berbasis kepada kelestarian dan pemanfaatan yang bijak. Dampak jangka panjangnya, sumberdaya ikan tersebut dapat dapat terus dimanfaatkan. Menurut Charles (2001) pengelolaan sistem perikanan tidak dapat dilepaskan dari 3 dimensi yakni (1) dimensi sumberdaya perikanan dan ekosistemnya; (2) dimensi pemanfaatan sumberdaya perikanan untuk kepentingan sosial ekonomi masyarakat; dan (3) dimensi kebijakan perikanan.
Berdasarkan ketiga dimensi tersebut, kepentingan pemanfaatan untuk kesejahteraan sosial ekonomi masyarakat cenderung lebih besar dibandingan dua dimensi lainnya dan belum mempertimbangkan keseimbangan ketiganya. Pendekatan yang dilakukan masih parsial dan belum terintegrasi dalam sebuah batasan ekosistem yang menjadi wadah dari sumberdaya ikan sebagai target pengelolaan. Oleh karenanya pendekatan terintegrasi melalui pendekatan ekosistem terhadap pengelolaan perikanan menjadi sangat penting. Salah satu metode pendekatan pengelolaan perikanan adalah dengan menggunakan pendekatan EAFM (Ecosystem Approach to Fisheries Management). Penilian terhadap indikator-indikator yang terdapat pada EAFM diharapkan dapat menjadi mekanisme penilaian pengelolaan perikanan pada suatu wilayah. Adapun indikator yang menjadi dasar penilaian keberlanjutan terhadap suatu pengelolaan perikanan meliputi 6 aspek yakni sumberdaya ikan, habitat dan ekosistem perairan, teknik penangkapan ikan, sosial, ekonomi, dan kelembagaan.

Daerah Sendangbiru di Kabupaten Malang merupakan salah satu daerah penghasil tuna terbesar di Jawa Timur. Daerah yang terletak di selatan Kabupaten Malang ini berbatasan langsung dengan Samudera Hindia sehingga memungkinkan perairan di sekitarnya memiliki keanekaragaman jenis ikan pelagis yang banyak. Ikan tuna merupakan salah satu komuditi unggulan dan merupakan jenis ikan yang banyak ditangkap oleh nelayan di Sendangbiru. Dalam perkembangannya, penggunaan rumpon banyak digunakan oleh nelayan pancing ulur untuk menangkap ikan tuna. Penggunaan rumpon terbukti efektif membantu nelayan untuk meningkatkan jumlah hasil tangkapan tuna. Peningkatan jumlah hasil tangkapan tuna dengan menggunakan rumpon juga terjadi di PPN Prigi (Ross et al. 2012). Menurut Nurani (2008) ikan tuna hasil tangkapan menggunakan 
pancing tonda memiliki ururan yang belum layak tangkap. Hal ini dikhawatirkan akan berdampak pada kelestarian sumberdaya ikan tuna.Penelitian ini bertujuan untuk menentukan tingkat keberlanjutan dari masingmasing domain atau aspek yang ada di dalam EAFM dan menentukan tingkat keberlanjutan kegiatan perikanan tuna di daerah Sendangbiru, Kabupaten Malang.

\section{METODOLOGI}

\section{Waktu dan Tempat Penelitian}

Penelitian dilakukan di Pelabuhan Perikanan Pantai (PPP) Pondokdadap, Dusun Sendangbiru, Desa Tambakrejo, Kecamatan Sumbermanjing Wetan, Kabupaten Malang, Provinsi Jawa Timur pada bulan AgustusSeptember 2016.

\section{Metode Pengumpulan Data}

Pada penelitian ini jenis data yang digunakan adalah data primer dan data sekunder. Data primer yang digunakan dalam penelitian ini meliputi 6 domain (aspek) yakni sumberdaya ikan, habitat dan ekosistem perairan, teknik penangkapan ikan, sosial, ekonomi kelembagaan. Masing-masing domain/aspek memiliki indikator-indikator tersendiri yang digunakan untuk membantu menilai tingkat keberlanjutan dari masingmasing domain. Data primer diperoleh dengan melakukan survey, observasi langsung dan melalui wawancara. Responden yang dipilih ditentukan dengan menggunakan teknik snowball sampling. Snowball sampling adalah suatu pendekatan untuk menemukan informan-informan (responden) kunci yang memiliki banyak informasi terkait dengan penelitian yang dilakukan (Salganik 2007). Pendekatan ini menggunakan, beberapa responden yang potensial dihubungi dan ditanya apakah mereka mengetahui orang lain (responden lain) dengan kriteria yang sudah ditentukan untuk keperluan penelitian. Kontak awal akan sangat membantu mendapatkan responden lainnya melalui rekomendasi. Teknik ini didukung juga dengan teknik wawancara dan survey lapangan. Wawancara dilakukan secara terstruktur menggunakan daftar pertanyaan (kuisioner). Menurut Salganik (2007) ukuran sampel yang dapat digunakan dalam menggunakan teknik ini yakni: (1) besar, dengan jumlah sampel lebih dari 30, (2) sedang, dengan jumlah sampel antara 10-30. Pada penelitian yang dilakukan jumlah sampel yang akan digunakan adalah 30 . Dari 30 sampel tersebut akan dibagi lagi ke dalam masing-masing responden. Responden tersebut meliputi kelompok nelayan, Dinas Perikanan dan Kelautan, pihak pengelola pelabuhan dan stakeholder yang ada, yang jumlahnya disesuaikan dengan keputuhan peneliti. Pengumpulan data sekunder diperoleh dari Dinas Kelautan dan Perikanan, penelitian sebelumnya, pihak pengelola $\mathrm{Pe}-$ labuhan Pondokdadap. Data yang dikumpulkan meliputi logbook perikanan yang terdapat di pelabuhan Pondokdadap, data produksi, dan data jumlah armada perikanan dan data lainnya yang dapat menunjang penelitian ini.

\section{Analisis Data}

Analisis terhadap tingkat keberlanjutan kegiatan perikanan tuna di perairan Sendangbiru dilakukan menggunakan pendekatan EAFM (ecosystem approach to fisheries management). EAFM merupakan sebuah konsep bagaimana untuk menyeimbangkan antara tujuan sosial ekonomi dalam pengelolaan perikanan, dengan tetap mempertimbangkan pengetahuan, informasi dan ketidakpastian tentang komponen biotik, abiotik dan interaksi manusia dalam ekosistem perairan melalui sebuah pengelolaan perikanan yang terpadu, komprehensif dan berkelanjutan (FAO 2003). Terdapat beberapa prinsip yang diperhatikan dalam penerapan pendekatan ekosistem dalam pengelolaan perikanan (EAFM), yakni: (1) kegiatan perikanan harus dikelola pada batas yang memberikan dampak yang dapat atau masih bisa ditoleransi oleh ekosistem di suatu daerah/perairan, (2) interaksi ekologis antar sumberdaya ikan dan ekosistemnya harus dijaga, (3) perangkat pengelolaan harus sesuai untuk semua distribusi sumberdaya ikan, (4) prinsip kehatihatian dalam pengambilan keputusan dalam pengelolaan perikanan, (5) tata kelola perikanan mencakup kepentingan sistem 
ekologi dan sistem manusia (FAO 2003). Pengelolaan perikanan melalui pendekatan EAFM sesungguhnya memfokuskan pada keterkaitan antara target spesies dengan ekosistem perairan dan segenap unsur terkait di dalamnya. Keterkaitannya tidak hanya dalam perspektif ekologi tapi juga antara sistem ekologis dengan sistem sosial sebagai unsur utama dari pengelolaan perikanan.

Penilaian indikator-indikator yang ada didalam EAFM merupakan sebuah sistem multikreteria yang berujung pada indeks komposit terkait dengan tingkat pencapaian sebuah pengelolaan perikanan sesuai dengan prinsip EAFM. Pendekatan komposit yang akan dipakai adalah pendekatan komposit sederhanadengan menggunakan pendekatan MCA (multi criteria analysis) yang mana sebuah set kreteria dibangun sebagai basis bagi analisis keragaan wilayah pengelolaan perikanan dilihat dari pendekatan ekosistem dalam pengelolaan perikanan melalui pengembangan indeks komposit dengan tahapan sebagai berikut (Budiarto 2015):

1. Menentukan kriteria untuk setiap indikator dari masing-masing domain/aspek yang terdapat di dalam EAFM (aspek habitat dan ekosistem perairan, teknik penangkapan ikan, sumberdaya ikan, sosial, ekonomi dan kelembagaan).

2. Menentukan batasan nilai (reference point) untuk masing-masing kreteria pada setiap indikator

3. Menentukan bobot untuk setiap indikator. Pembobotan ditetapkan dalam skala 0-100.Indikator yang memiliki bobot besar dianggap memiliki nilai kepentingan paling tinggi dalam domain tersebut. Pembobotan maksimal tiap domain/aspek adalah 100 yang dibagi habis dalam setiap indikator
4. Mengkaji keragaan masing-masing indikator yang diuji

5. Menentukan nilai skor untuk setiap indikator dengan menggunakan skor Likert (berbasis ordinal 1, 2, 3) sesuai dengan keragaan masing-masing indikator. Nilai 1 merupakan skor terendah yang menandakan keadaan yang jelek (merah), dan nilai 3 merupakan skor tertinggi yang menandakan keadaan yang bagus (hijau). Pemberian skor dan warna dapat dilihat pada Tabel 1. Dari proses pemberian skor tersebut kita bisa mengetahui indikator-indikator mana yang berada dalam kondisi bagus ataupun jelek.

Tabel 1 Nilai skor indikator

\begin{tabular}{cc}
\hline Skor Indikator & Deskripsi \\
\hline 1 & Jelek / buruk \\
\hline 2 & Sedang \\
\hline 3 & Bagus \\
\hline
\end{tabular}

6. Menentukan nilai dari masing-masing indikator dengan formula:

\section{Nilai Indikator $=$ Bobot $\mathbf{x}$ Nilai Skor}

7. Menentukannilai dari masing-masing aspek/domain dengan cara mengakumulasikan nilai indikator yang didapat didalam setiap aspek.

8. Nilai dari masing-masing domain/aspek kemudian dianalisis dengan menggunakan analisis komposit sederhana berbasis rataan aritmatik yang kemudian ditampilkan dalam bentuk model bendera dengan kreteria dapat dilihat pada Tabel 2. Indeks komposit ini merupakan nilai konversi nilai total setiap aspek/domain EAFM. Proses

Tabel 2 Tren ukuran ikan tuna yang tertangkap

\begin{tabular}{ccc}
\hline Tahun & Ukuran Rata-rata ikan tuna (cm) & Sumber \\
\hline 2012 & $141 \mathrm{~cm}$ & Andamari (2012) \\
2013 & $103 \mathrm{~cm}$ & Katun (2013) \\
2014 & $102 \mathrm{~cm}$ & Nurani (2014) \\
2016 & $90 \mathrm{~cm}$ & Penelitian ini \\
\hline
\end{tabular}


konversi ini dilakukan untuk memperoleh batasan yang baku dari nilai EAFM. Nilai total dari perkalian komponen EAFM selanjutnya di konversi dalam skala 33-100. Konversi ini diperlukan untuk memudahkan pengkatagorian suatu domain EAFM. Nilai skala setiap domain/aspek yaitu:

$$
\begin{aligned}
& \text { Nk-i }=\frac{C a t-i}{C a t-i m a x} \times 100 \\
& \text { Keterangan: } \\
& \text { Cat }=\text { niai total yang didapat } \\
& \text { dalam sutu aspek/domain } \\
& \text { Cat-imax }=\text { nilai maksimal dalam } \\
& \text { suatu aspek/domain yang } \\
& \text { diperoleh saat semua } \\
& \text { indikator memiliki skor } 3
\end{aligned}
$$

9. Menentukan nilai komposit total dari seluruh domain/aspek EAFM yang dikaji. Nilai komposit ditentukan dari nilai rata-rata dari seluruh domain yang dikaji dalam wilayah EAFM. Hasil ini kemudian dikonversi menjadi nilai dengan skala 33-100. Nilai 100 termasuk paling tinggi dan paling baik kondisinya, dan nilai yang rendah tergolong paling buruk kondisinya. Nilai yang didapat kemudian dideskripsikan atas 5 kelompok atau kategori. Kelima kategori ini menggambarkan 5 tingkatan status pengelolaan perikanan suatu wilayah. Pengklasifikasian nilai EAFM dapat dilihat pada Tabel 3 .

\section{HASIL DAN PEMBAHASAN}

\section{Domain Sumberdaya ikan}

Nilai skor indikator CPUE yang diperoleh adalah 1 . Hal ini menunjukan bahwa telah terjadi penurunan tajam $(>25 \%)$ terhadap CPUE di daerah Sendangbiru. Hasil ini diperoleh dari perhitungan CPUE pada tahun 2013 hingga tahun 2015. Pada tahun 2014 telah terjadi penurunan CPUE sebesar 43\%, dan pada 2015 terjadi penurunan sebesar 9\%. Penurunan tajam juga pernah terjadi pada tahun 2006 sebesar 37\% (Hulaifi 2011). Tren CPUE yang cenderung mengalami penurunan merupakan indikasi terjadinya penurunan stok ikan tuna sebagai akibat dari upaya penangkapan ikan tuna yang tinggi di daerah Sendangbiru. Tren penurunan CPUE juga dapat dijadikan indikator bahwa kegiatan perikanan tuna di daerah Sendangbiru telah terjadi overfishing dan telah terjadi tekanan terhadap penangkapan tuna. Sumberdaya perikanan merupakan common property yang berarti dimiliki bersama memungkinkan terjadinya pemanfaatan secara berlebih sehingga menimbulkan inefisiensi dalam pemanfaatan input, return yang rendah dan overfishing. Pillai dan Satheeshkumar (2012) menyebutkan produksi ikan tuna di Samudera Hindia menurun pada tahun 2008. Analisis data secara jelas menunjukan bahwa populasi ikan tuna di Samudera Hindia mengalami overexploited.

Nilai skor indikator tren ukuran ikan adalah 1. Hal ini menunjukan bahwa ikan tuna yang tertangkap memiliki ukuran yang semakin kecil. Hasil wawancara terhadap nelayan yang sudah melakukan kegiatan penangkapan ikan tuna selamalebih dari 5 tahun juga menyebutkan telah terjadi penurunan ukuran ikan tuna yang tertangkap meskipun tidak terlalu signifikan. Beberapa

\begin{tabular}{|c|c|c|}
\hline \multicolumn{2}{|c|}{ Rentang Nilai } & \multirow{2}{*}{ Deskripsi } \\
\hline Rendah & Tinggi & \\
\hline 33.33 & 46.17 & Buruk atau kurang dalam menerapkan EAFM \\
\hline 46.67 & 59.5 & Kurang dalam menerapkan EAFM \\
\hline 60 & 72.83 & Sedang dalam menerapkan EAFM \\
\hline 73.33 & 86.17 & Baik dalam menerapkan EAFM \\
\hline
\end{tabular}
hasil penelitian sebelumnya juga menyebutkan tren penurnan ukuran ikan tuna tertangkap (Tabel 3). Penurunan tuna yang tertangkap dapat diakibatkan oleh semakin tingginya intensitas penangkapan terhadap ikan tuna dan dapat juga mengindikasikan telah terjadinya

Tabel 3 Batasan skor nilai EAFM 


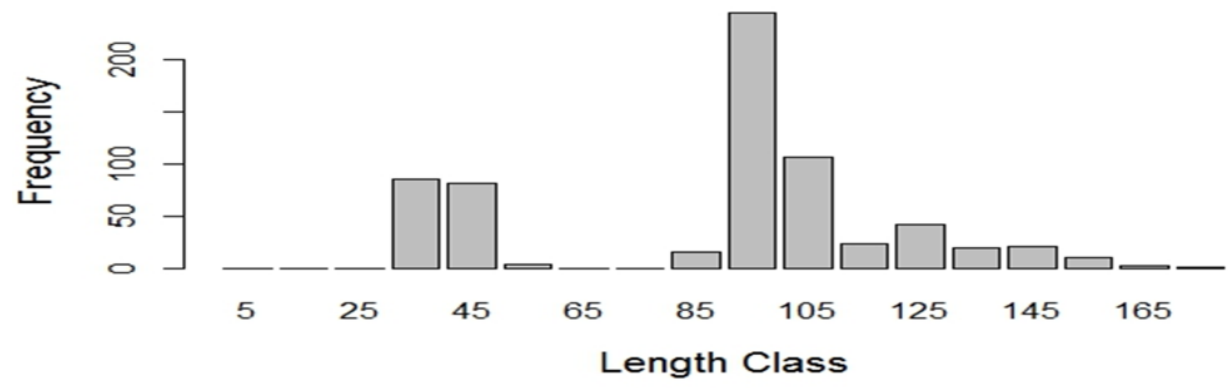

Gambar 1 Sebaran panjang ikan tuna yang tertangkap

tangkapan berlebih terhadap sumberdaya ikan tuna.

Nilai skor indikator proporsi ikan juvenile yang ditangkap adalah 3. Nilai skor tersebut menunjukan bahwa ikan juvenile yang tertangkap sedikit $(<30 \%)$. Dari sampling yang dilakukan selama penelitian, terdapat 26\% dari total ikan tuna yang tertangkap yang tergolong belum mencapai dewasa. Sebaran panjang ikan tuna yang tertangkap dapat dilihat pada Gambar 1. Tertangkapnya ikan tuna muda ini disebabkan karena kesengajaan nelayan untuk menangkap ikan tersebut. Alasan beberapa nelayan menangkap ikan tuna muda tersebut adalah karena ingin mendapatkan penghasilan tambahan dari penjualan ikan tuna muda yang ditangkap. Adapula nelayan yang menangkap ikan tuna muda ini karena adanya permintaan dari juragan tempat nelayan meminjam modal untuk melaut. Nelayan biasanya menangkap ikan tunamuda ini dalamperjalan pulang menuju pelabuhan Pondodokdadap.

Nilai skor indikator komposisi spesies hasil tangkapan adalah 3. Hal ini mengindikasikan bahwa proporsi spesies target (ikan tuna) mendominasi hasil tangkapan
(>30\%). Berdasarkan data dari Pelabuhan Pondokdadap pada bulan Juni 2016, ikan tuna merupakan ikan yang dominan tertangkap yakni sekitar $64 \%$ dari total produksi pada bulan tersebut seperti yang ditunjukan pada Gambar 2. Selanjutnya disusul oleh ikan cakalang (20\%), tongkoldan layang (2\%), marlin (1\%) dan terakhir lemadang (0.01\%). Dari hasil pengamatan langsung yang dilakukan juga terlihat bahwa ikan tuna merupakan spesies target dominan yang tertangkap oleh nelayan pancing ulur di Sendangbiru. Nilai skor range collapse sumberdaya ikan adalah 2. Hasil yang diperoleh menunjukan bahwa lokasi penangkapan ikan tuna yang dilakukan oleh nelayan relatif tetap. Hal ini dikarenakan nelayan sudah menggunakan rumpon sebagai alat bantu pengumpul ikan. Rumpon yang dipasang terletak di lintang $10^{\circ}$ hingga lintang $13^{\circ}$ serta bujur $111^{\circ}$ hingga bujur $113^{\circ}$ yang berjarak \pm 180-250 mil dari Pelabuhan Pondokdadap. Satu rumpon biasanya dimiliki oleh beberapa kelompok nelayan, ada juga yang dimiliki secara pribadi. Bagi nelayan keberadaan rompon sangat membantu untuk mengefisienkan pencarian fishing ground sehingga lebih menghemat biaya.

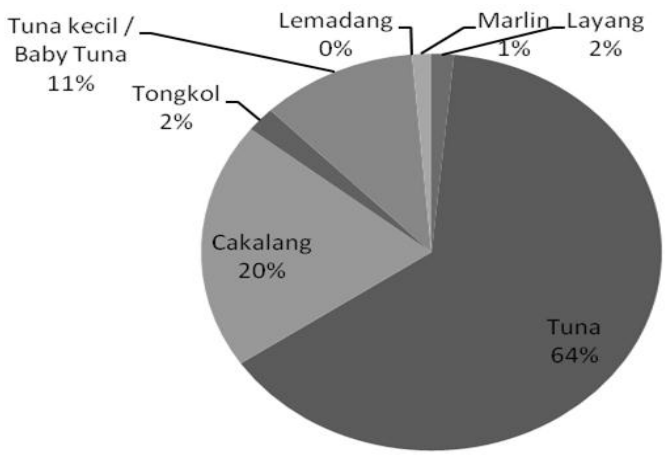

Gambar 2 Komposisi ikan hasil tangkapan di Pelabuhan Pondokdadap 
Nilai skor untuk indikator spesies ETP adalah 3. Hasil ini menunjukan dalam aktivitas penangkapan ikan tuna tidak ada spesies ETP yang tertangkap. Berdasarkan informasi nelayan dan juga pengamatan selama dilakukannya penelitian tidak ditemukan adanya spesies ETP yang tertangkap. Spesies ETP (Endangered

species, Threatened species, and protected species) yang dimaksud antara lain hiu, penyu, lumba-lumba. Jikapun tertangkap, oleh nelayan biasanya akan langsung dilepas. Hal ini dikarenakan nelayan sudah paham dan sadar akan peraturan akan pelarangan penangkapan spesies ikan yang termasuk spesies ETP.

Hasil penilaian penilaian indikator dalam domain/aspek sumberdaya ikan dapat selengkapnya dilihat pada Tabel 4 .

\section{Domain/aspek Habitat dan Ekosistem Perairan}

Nilai skor terhadap indikator kualitas perairan adalah 3. Perolehan skor tersebut menandakan bahwa kualitas perairan yang dimiliki perairan Sendangbiru masih baik atau belum tercemar. Kualitas perairan di perairan Sendangbiru secara umum masih dalam batasbatas normal. Hal ini ditunjukan dengan parameter salinitas sekitar 29.8\%-33\%, suhu perairan sekitar $29-30{ }^{\circ} \mathrm{C}$, DO sekitar $5.16 \mathrm{mg} / \mathrm{l}$ - $13.3 \mathrm{mg} / \mathrm{l}$, tingkat kecerahan sekitar 3.7 - 4.6 meter, dan kecepatan arus sekitar 0.65 $\mathrm{m} / \mathrm{s}$.Nilai skor indikator status ekosistem lamun adalah 1. Hasil ini diperoleh bukan karena tutupan ekosistem lamun yang rendah maupun keragamannya yang rendah melainkan karena tidak ditemukannya ekosistem lamun di perairan Sendangbiru. Hal ini bisa dijadikan masukan kedepannya terhadap penilaian indikator ini bila di dalam suatu daerah tidak ditemukan adanya ekosistem lamun apakah harus dihapuskan ataupun tidak diikut sertakan dalam penilaian terhadap aspek habitat dan ekosistem perairan.

Nilai skor indikator status ekosistem mangrove adalah 1 . Status ekosistem mangrove yang ditemukan di daerah Sendangbiru memiliki kerapatan yang sangat rendah yakni kurang dari 1000 pohon/ha. Luasan kawasan mangrove sekitar kurang lebih 81 ha. Rendahnya kerapatan dan luasan kawasan mangrove di daerah ini disebabkan oleh terjadinya banyak alih fungsi lahan mangrove menjadi daerah pemukiman dan juga menjadi kebun yang dilakukan masyarakat setempat.Selain itu indeks diversitas mangrove di Sendangbiru sebesar 0.72-1.01, yang mengindikasikan bahwa kawasan mangrove di daerah tersebut diversitasnya buruk atau rendah (Pradana 2011).Untuk memulihkan kawasan mangrove Pokmaswas (Kelompok Masyarakat Pengawas) setempat melakukan penanaman bibit-bibit mangrove baik secara swadaya maupun dari bantuan dinas terkait. Diharapkan beberapa tahun mendatang kerapatan kawasan mangrove dapat bertambah.

Nilai skor indikator status ekosistem terumbu karang adalah 2. Hasil ini menunjukan bahwa ekosistem terumbu karang yang ada memiliki tutupan sedang $(>25 \%$ $<50 \%)$. Berdasarkan hasil wawancara dengan Pokmaswas setempat diketahui luas terumbu karang di perairan ini sekitar 20 Ha dengan tutupan sedang. Di Malang Selatan terumbu karang dengan tutupan kurang dari 50\%

Tabel 4 Hasil penilaian indikator dalam domain/aspek sumberdaya ikan

\begin{tabular}{lc}
\hline Indikator & Nilai Skor \\
\hline CPUE baku & 1 \\
\hline Tren ukuran ikan & 2 \\
\hline Proporsi ikan juvenile yang ditangkap & 3 \\
\hline Komposisi spesies hasil tangkapan & 3 \\
\hline Range collapse sumberdaya ikan & 2 \\
\hline Spesies ETP & 3 \\
\hline
\end{tabular}


ditemukan juga dilokasi Kondang Merak dengan tutupan 29\% dan Sendangbiru sebesar 36\% (Luthfi 2015). Oleh Pokmaswas daerah ini sangat dikelola dengan baik untuk menjaga kelestarian alam dan lingkungannya. Diharapkan dengan dijaganya kelestarian di daerah tersebut akan semakin banyak ikanikan karang yang memijah. Pengelolaan juga dilakukan dengan pembuatan aturan yang melarang warga sekitar untuk menangkap ikan di daerah sekitar terumbu karang dan juga pelarangan kapal-kapal untuk melintas di kawasan tersebut. Sejauh ini peraturanperaturan tersebut sudah berjalan efektif. Kawasan ini juga dijadikan salah satu tempat wisata unggulan yang dikelola oleh Pokmaswas beserta Perhutani. Sistem kuotapun diberlakukan untuk membatasi jumlah pengunjung. Perhari jumlah wisatawan yang diperbolehkan berkunjung hanya 200 sampai 300 orang. Hal ini dilakukan untuk menjaga keasrian dan kelestarian daerah tersebut.

Nilai skor untuk indikator habitat unik /khusus adalah 3. Hasil ini menunjukan bahwa di perairan sendangbiru terdapat habitat unik /khusus dan dikelolan dengan baik. Habitat unik dan khusus yang dimaksud adalah kawasan terumbu karang yang ada di pantai 3 warna. Oleh Pokmaswas setempat daerah ini dikelola dengan baik dan hati-hati dan diharapkan dapat dijadikan tempat memijah bagi ikan-ikan karang.

Nilai skor untuk indikator perubahan iklim terhadap kondisi perairan dan habitat adalah 2. Hal ini menunjukan bahwa masyarakat mengetahui adanya dampak perubahan iklim terhadap kondisi perairan namun belum memiliki strategi untuk menghadapinya. Dampak yang paling dirasakan oleh warga akibat perubahan iklim adalah ekosistem terumbu karang. Pengelolaan kawasan terumbu karang dikawasan ini mengalami tantangan cukup besar yakni adanya kerusakan terumbu karang sebagai akibat dari perubahan iklim. Menurut Mahmudi (2003) tingkat kerusakan terumbu karang di daerah ini sudah mencapai $37.34 \%$. Setiap tahunnya terdapat karang yang mengalami pemutihan (bleaching). Hal ini dikarenakan suhu air laut mengalami kenaikan. Bagi Pokmaswas hal ini sudah diketahui namun mereka belum memiliki strategi untuk menghadapinya. Menurut Luthfi et al. (2016) kerusakan terumbu karang yang ada di daerah Sendangbiru dapat disebabkan oleh aktifitas penangkapan ikan yang tinggi dengan menggunakan alat tangkap tidak ramah lingkungan. Penyebab lainnya adalah limbah dari aktifitas manusia yang bermukim di dekat perairan.

Hasil penilaian indikator dalam domain/aspek habitat dan ekosistem secara keseluruhan dapat dilihat pada Tabel 5.

\section{Domain/aspek Teknik Penangkapan Ikan}

Nilai skor indikator metode penangkapan ikan yang bersifat destruktif dan atau ilegal adalah 3 . Hasil ini menunjukan bahwa frekuensi pelanggaran yang terjadi akibat dari metode penangkapan yang bersifat destruktif dan ilegal kurang dari 5 kasus pertahun. Metode penangkapan ikan yang bersifat destruktif atau illegal dapat secara langsung mengakibatkan kerusakan sumberdaya ikan beserta ekosistem di

Tabel 5 Hasil penilaian indikator dalam domain/aspek habitat dan ekosistem perairan

\begin{tabular}{ll}
\hline Indikator & Nilai \\
\hline Kualitas perairan & 3 \\
\hline Status ekosistem lamun & 1 \\
\hline Status ekosistem mangrove & 1 \\
\hline Status ekosistem terumbu karang & 2 \\
\hline Habitat unik / khusus & 3 \\
\hline Perubahan iklim terhadap kondisi perairan dan habitat & 2 \\
\hline
\end{tabular}


dalamnya. Metode destruktif tersebut meliputi penggunaan bom, racun sianida maupun potassium. Penggunaan alat tangkap yang destruktif ataupun tidak ramah lingkungan juga dapat menimbulkan kerusakan. Penggunaan alat tangkap yang tidak ramah lingkungan sudah diatur dalam undangundang dan sudah seharusnya ditaati oleh semua pihak. Nilai skor 3 pada indikator metode penangkapan ikan yang bersifat destruktif atau illegal menunjukan bahwa nelayan-nelayan di Sendangbiru menggunakan metode penangkapan yang ramah lingkungan. Hal ini tercermin dari jumlah pelanggaran yang dilakukan hampir tidak ada. Informasi ini diperoleh dari hasil wawancara terhadap pihak PSDKP di pelabuhan Pondokdadap. Untuk menangkap ikan tuna, seluruh nelayan menggunakan alat tangkap pancing ulur dan menggunakan alat bantu penangkapan yakni batu yang diikatkan pada tali pancing. Penggunaan batu juga dimaksudkan untuk mempercepat turunnya mata pancing. Selain itu gerakan karena adanya hentakan dari batu tersebut dianggap dapat menarik perhatian ikan sehingga ikan akan menyambar mata pancing. Alat tangkap pancing ulur dikategorikan sebagai alat tangkap yang ramah lingkungan dibandingkan dengan alat tangkap lainnya, karena ukuran mata pancing dan jenis umpannya dapat disesuaikan dengan spesies target yang diinginkan (Monintja 1997).

Nilai skor indikator modifikasi alat penangkapan ikan dan alat bantu penangkapan ikan adalah 3. Nilai skor ini mengindikasikan bahwa modifikasi alat penangkapan ikan dan alat bantu penangkapan menghasilkan hasil tangkapanikan tuna yang didominasi oleh ikan yang memiliki ukuran lebih besar dari Lm. Modifikasi alat tangkap pancing ulur yang dilakukan nelayan hanya sebatas penambahan panjang jaring dan penggunaan batu sebagai alat bantu. Hal ini dikarenakan ikan tuna yang tertangkap semakin dalam. Rumpon juga digunakan nelayan sebagai alat bantu pengumpul ikan untuk memudahkan nelayan mencari fishing ground. Penggunaan rumpon sebagai alat bantu pada perikana tuna di Sendangbiru sangat diminati oleh nelayan. Satu rumpon biasanya dimanfaatkan oleh 5-9 kapal dengan jarak pemasangan rumpon antara 10-15 mil. Pemanfaatan rumpon hanya boleh digunakan oleh anggota kelompok, dan kelompok diluar itu tidak diperbolehkan memanfaatkan rumpon kelompok lain, kecuali mendapatkan izin dari yang memiliki rumpon.

Selama dilakukannya penelitian didapatkan hasil sekitar 74\% (sebaran ukuran hasil tangkapan ikan tuna dapat dilihat pada Gambar 1) ikan tuna yang tertangkap memiliki panjang lebih besar dari Lm (Lm tuna $90 \mathrm{~cm}$ ).

Nilai skor indikator kapasitas perikanan dan upaya penangkapan adalah 2. Kapasitas perikanan dan upaya penangkapan yang ada di daerah Sendangbiru menunjukan nilai yang tetap (rasio kapasitas penangkapan =1). Berdasarkan data pelabuhan Pondokdadap jumlah nelayan yang beroprasi di daerah Sendangbiru dari tahun 2013-2015 menunjukan jumlah yang tetap. Nelayan tersebut terdiri dari nelayan lokal dan nelayan andon.

Nilai skor indikator selektifitas penangkapan adalah 3. Hal ini menunjukan bahwa nelayan Sendangbiru sebagian besar menggunakan alat tangkap yang ramah lingkungan dalam menangkap ikan tuna. Sebagian besar nelayan tuna di Sendangbiru menggunakan pancing ulur dalam menangkap ikan tuna. Pancing ulur termasuk jenis alat tangkap yang selektif. Umumnya pancing bisa memilih jenis dan ukuran ikan yang menjadi target penangkapan.

Nilai skor indikator kesesuaian fungsi dan ukuran kapal penangkapan ikan dengan dokumen legal adalah 3 yang berarti kesusaian kapal dengan dokumen yang ada sangat tinggi. Berdasarkan hasil wawancara terhadap pegawai PSDKP di pelabuhan Pondokdadap hampir lebih dari 80\% (dari total 3170 armada yang beroprasi) kapal yang beroprasi di Sendangbiru memiliki kesesuaian fungsi dan ukuran sebagaimana yang tercantum di dalam dokumen legal. Pengukuran langsung yang dilakukan terhadap salah satu kapal pancing ulur nelayan juga menunjukan kesesuaian dengan dokumen kapal yang ada. 
Nilai skor indikator sertifikasi awak kapal sesuai dengan peraturan adalah 1 . Nilai skor tersebut menunjukan bahwa kepemilikan sertifikat bagi awak kapal masih sangat rendah. Dari hasil pengamatan dan wawancara terhadap beberapa awak kapal, sertifikat hanya dimiliki oleh nahkoda kapal sedangkan hampir seluruh ABK tidak memiliki sertifikasi. Sertifikat yang dimiliki oleh nahkoda adalah surat keterangan kecakapan 60 mil. Belum adanya peraturan yang mengatur mengenai kepemilikan sertifikat keahlian pengoperaisan suatu alat tangkap bagi ABK kapal menyebab tidak adanya ABK yang memiliki sertifikat keahlian.

Hasil penilaian indikator dalam domain/ aspek teknik penangkapan ikan secara keseluruhan dapat dilihat pada Tabel 6 .

\section{Domain/ Aspek Ekonomi}

Nilai skor indikator kepemilikan aset yang diperoleh adalah 3 yang menunjukan bahwa nilai aset yang dimiliki nelayan bertambah dari usaha perikanan tuna. Dari hasil wawancara terhadap beberapa nelayan pancing ulur menyebutkan bahwa kegiatan penangkapan ikan tuna dapat membuat nelayan mampu untuk menambah jumlah aset mereka setiap tahunnya. Wawancara dilakukan terhadap nahkoda dan ABK kapal pancing ulur. Aset yang dimaksud di dalam penelitian ini meliputi tabungan, peralatan elektronik (tv, kulkas, mesin cuci, dll), HP, kendaraan motor, tanah, dan lain-lain.

Nilai skor indikator pendapatan rumah tangga perikanan adalah 3 . Hal ini menunjukan bahwa pendapatan nelayan pancing ulur di Sendangbiru memiliki penghasilan diatas atau sama dengan UMR Kabupaten Malang. Berdasarkan Peraturan Gubernur No 68 tahun 2015 tentang upah minimum kota/Kabupaten di provinsi Jawa Timur, UMK (Upah Minimum Kabupaten) Kabupaten Malang sebesar Rp. 2.188.000,00. Berdasrkan hasil wawancara terhadap nelayan pancing ulur di Sendangbiru, pendapatan nelayan berkisar antara Rp. 2.500.000 hingga Rp. 3.000.000 per trip untuk posisi sebagai ABK. Sedangkan untuk nahkoda dan pemilik kapal berkisar antara Rp. 5.000.000 hingga Rp. 8.000 .000 per trip. Dengan demikian pendapatan nelayan pancing ulur dianggap sudah layak karena nilainya sudah melebihi UMK. Pembagian pendapatan antara ABK dengan pemilik kapal adalah 50:50 dari pendapatan bersih yang diperoleh. Adapun jumlah ABK dalam 1 armada penangkapan berjumlah 5-6 orang termasuk nahkoda. Adapula pembagian pendapatan sudah ditentukan diawal sebelum ABK diajak bekerja, sehingga tidak terpengaruh seberapa besar hasil yang diperoleh.

Nilai skor indikator rasio tabungan yang diperoleh adalah 3 . Nilai skor tersebut menunjukan bahwa rasio tabungan yang diperoleh dari kegiatan perikanan tuna lebih dari bunga kredit pinjaman. Dari hasil wawancara terhadap beberapa nelayan pancing ulur, pengeluaran rumah tangga nelayan di Sendangbiru rata-rata sebesar Rp. 1.000.000 hingga Rp. 2.000.000 per bulan untuk kebutuhan sehari-hari dan lain-lain. Dengan pendapatan yang nelayan dapatkan rasio tabungan yang diperolehpun positif. Adanya rasio tabungan yang positif menyebabkan banyak nelayan memiliki kemampuan untuk menambah jumlah asset mereka, diantaranya untuk membeli kapal baru, membeli peralatan

Tabel 6 Hasil penilaian indikator dalam domain/aspek teknik penangkapan ikan

\begin{tabular}{lc}
\hline Indikator & Nilai \\
\hline Metode penangkapan ikan yang bersifat destruktif dan atau illegal & 3 \\
\hline Modifikasi alat penangkapan ikan dan alat bantu penangkapan & 3 \\
\hline Kapasitas perikanan dan upaya penangkapan & 2 \\
\hline Selektivitas penangkapan & 3 \\
\hline Kesesuaian fungsi dan ukuran kapal penangkapan ikan dengan dokumen legal & 3 \\
\hline Sertifikasi awak kapal perikanan sesuai dengan peraturan & 1 \\
\hline
\end{tabular}


rumah tangga dan elektronik, motor, investasi dan lain sebagainya.

Hasil penilaian indikator dalam domain/aspek ekonomi secara keseluruhan dapat dilihat pada Tabel 7.

Tabel 7 Hasil penilaian indikator dalam domain/aspek ekonomi

\begin{tabular}{lc}
\hline Indikator & Nilai \\
\hline Kepemilikan asset & 3 \\
\hline Pendapatan rumah tangga perikanan & 3 \\
\hline Rasio tabungan & 3 \\
\hline
\end{tabular}

\section{Domain/Aspek Sosial}

Nilai skor indikator partisipasi pemangku kepentingan adalah 3 yang mengindikasikan bahwa keterlibatan pemangku kepentingan yang ada di Sendnagbiru sangat tinggi. Pengukuran partisipasi pemangku kepentingan bertujuan untuk melihat keaktifan pemangku kepentingan yang ada dalam seluruhkegiatan pengelolaan dan pemanfaatan sumberdaya ikan. Dari hasil wawancara dengan beberapa stakeholder yang ada di Sendangbiru didapatkan hasil bahwa partisipasi pemangku kepentingan yang ada di daerah Sendangbiru tergolong tinggi. Hal ini disebabkan karena seluruh pemangku kepentingan yang ada turut serta dalam pengelolaan dan pemanfaatan sumberdaya ikan. Pemangku kepentingan yang dimaksud meliputi pihak pelabuhan Pondokdadap, PSDKP, pengusaha perikanan, nelayan, KUD, DKP kabupaten dan provinsi, dan Pokmaswas setempat.

Nilai skor indikator konflik perikanan diperoleh nilai 2. Hal ini menunjukan bahwa konflik yang terjadi dalam pemanfaatan sumberdaya ikan sebanyak 2-5 kali dalam 1 tahun. Konflik yang terjadi di daerah
Sendangbiru diantaranya melibatkan nelayan luar Sendangbiru seperti nelayan purse seine asal Pekalongan dan Tuban. Penyebab konflik adalah karena nelayan Pekalongan menangkap ikan di rumpon milik nelayan pancing ulur. Frekuensi terjadinya konflik tidak lebih dari 5 kali dalam setahun. Selain dengan nelayan luar juga pernah terjadi konflik dengan sesame nelayan Sendangbiru. Penyebabnya karena pemanfaatan rumpon yang bukan miliknya. Namun dengan sudah dibuatnya kesepakan antar nelayan dalam pemanfaatan rumpon tersebut diharapkan frekuensi terjadinya konflik semakin jarang terjadi.

Nilai skor indikator pemanfaatan pengetahuan lokal dalam pengelolaan sumberdaya ikan adalah 1. Hasil ini menunjukan bahwa tidak ada pemanfaatan pengetahuan lokal dalam pengelolaan sumberdaya ikan khususnya ikan tuna yang ada di daerah Sendangbiru. Dari hasil wawancara terhadap pihak pelabuhan Pondokdadap, pengetahuan tentang penangkapan ikan tuna hingga lebih dari 180 mil dibawa oleh nelayan andon (nelayan pendatang) yang umumnya berasal dari Sulawesi. Pemanfaatan rumpon sebagai alat bantu pengumpul ikan untuk menangkap tuna juga dikenalkan oleh nelayan pendatang.

Hasil penilaian indikator dalam domain/aspek sosial secara keseluruhan dapat dilihat pada Tabel 8 .

\section{Domain/aspek Kelembagaan}

Nilai skor yang diperoleh indikator kepatuhan terhadap prinsip-prinsip perikanan yang bertanggung jawab adalah 1. Hal ini menunjukan bahwa kepatuhan terhadap prinsip-prinsip perikanan yang bertanggung jawab dalam pengelolaan perikanan masih sangat kurang. Tercermin dari banyaknya

Tabel 8 Hasil penilaian indikator domain/aspek sosial

\begin{tabular}{lc}
\hline Indikator & Nilai \\
\hline Partisipasi pemangku kepentingan & 3 \\
\hline Konflik perikanan & 2 \\
\hline $\begin{array}{l}\text { Pemanfaatan pengetahuan lokal dalam pengelolaan sumberdaya } \\
\text { ikan (termasuk di dalamnya TEK, Traditional Ecological Knowledge) }\end{array}$ & 1 \\
\hline
\end{tabular}


Tabel 9 Hasil penilaian indikator EAFM dalam domain kelembagaan

\begin{tabular}{ll}
\hline Indikator & Nilai \\
\hline $\begin{array}{l}\text { Kepatuhan terhadap prinsip-prinsip perikanan yang bertanggug } \\
\text { jawab dalam pengelolaan perikanan yang telah ditetapkan }\end{array}$ & 1 \\
\hline Kelengkapan aturan main dalam pengelolaan perikanan & 3 \\
\hline Mekanisme pengambilan keputusan & 3 \\
\hline Rencana pengelolaan perikanan & 3 \\
\hline $\begin{array}{l}\text { Tingkat sinergisitas kebijakan dan kelembagaan pengelolaan } \\
\text { perikanan }\end{array}$ & 3 \\
\hline Kapasitas pemangku kepentingan & 3 \\
\hline
\end{tabular}

pelanggaran yang dilakukan oleh nelayan pancing ulur di Sendangbiru ( $>5$ kali terjadi pelanggaran). Berdasarkan hasil pengamatan dan wawancara terhadap pegawai PSDKP di Pelabuhan Pondokdadap pelanggaran yang sering dilakukan oleh nelayan adalah pelanggaran dokumen. Dokumen tersebut meliputi surat izin berlayar dan dokumen kapal. Dalam 1 tahun bisa terjadi lebih dari 100 pelanggaran yang terjadi. Menurut nelayan terdapat hambatan dalam proses pengurusan administrasi seperti lamanya mengurus suratsurat kelengkapan kapal dan jauhnya lokasi pengurusan karena harus keluar Kabupaten, dan juga karena biaya yang harus dikeluarkan. Meskipun dengan penegakan peraturan yang dilakukan oleh instansi terkait semakin ketat nelayan nekad untukberlayar tanpa surat-surat yang lengkap untuk memperoleh penghasilan.

Nilai skor indikator kelengkapan aturan main dalam pengelolaan perikanan adalah 3 , yang menunjukan bahwa penegakan hukum terhadap aturan-aturan yang ada sudah berjalan efektif. Peraturan yang lengkap dan penegakan hukum menjadi dasar dalam pelaksanaan pengelolaan perikanan yang bertanggung jawab. Adapun peraturan yang berlaku dalam pengelolaan perikanan di daerah ini diantaranya Pergub No 94 tahun 2008, Permen Kelautan Perikanan No 45 tahun 2015 tentang SLO (Surat Laik Operasi), Permen Kelautan Perikanan No 36 Tahun 2014 tentang nelayan andon, Permen Kelautan Perikanan no 13 Tahun 2012 tentang sertifikasi hasil tangkapan dan Peraturan Dirjen PSDKP No 10 tentang petunjuk teknis verifikasi pendaratan ikan. Penegakan aturan-aturan sudah berjalan dengan baik dan instansi-instansi yang terkait didalamnya saling mendukung seperti TNI AL, Polisi Air, PSDKP dan pihak Pelabuhan Pondokdadap.

Nilai skor indikator mekanisme pengambilan keputusan adalah 3 , yang menandakan terdapat mekanisme (SOP) yang dijalankan dan sudah berjalan efektif. Contoh mekanisme yang ada terkait dengan syarat dan prosedur pembuatan Kartu Tanda Pengenal Nelayan Andon dan juga Perijinan Usaha Perikanan Tangkap (SIUP/SIPI/SIKPI) yang sesuai dengan Pergub Jatim No. 77/Th.2010. Dari hasil wawancara yang dilakukan terhadap Kepala Pelabuhan Pondodokdadap dukungan dari pihak terkait dalam melaksanakan SOP tersebut sudah sangat baik dan pihak stakeholder juga dapat menerima SOP yang berlaku didaerah setempat.

Nilai skor indikator rencana pengelolaan perikanan adalah 3 . Hal ini menunjukan bahwa pihak pelabuhan Pondokdadap memiliki RPP dan telah dijalankan sepenuhnya. Rencana pengelolaan perikanan (RPP) diperlukan sebagai standar operasional dalam melaksanakan tata kelola perikanan yang bertanggung jawab. Berdasarkan hasil wawancara terhadap pegawai dan Kepala Pelabuhan Pondokdadap diketahui bahwa Pelabuhan Pondokdadap telah memiliki RPP untuk pengelolaan perikanan tuna dan sudah dijalankan dengan baik.

Nilai skor dari indikator tingkat sinergisitas kebijakan dan kelembagaan pengelolaan perikanan adalah 3 . Hal ini menunjukan bahwa sinergi antara lembaga sudah berjalan baik. Tingkat sinergisitas antar 
Tabel 10 Nilai setiap domain/aspek EAFM di daerah Sendangbiru

\begin{tabular}{lcc}
\hline Domain & Nilai Domain & Keterangan \\
\hline Sumberdaya ikan & 63.33 & Sedang \\
\hline Habitat dan ekosistem perairan & 71.67 & Sedang \\
\hline Teknik penangkapan ikan & 91.67 & Sangat Baik \\
\hline Ekonomi & 100 & Sangat Baik \\
\hline Sosial & 71.67 & Sedang \\
\hline Kelembagaan & 83.33 & Sangat Baik \\
\hline Rata-rata agregat & 80.28 & Baik \\
\hline
\end{tabular}

kebijakan dan kelembagaan dalam pengelolaan perikanan merupakan keterpaduan gerak dan langkah antar lembaga dan antar kebijakan dalam pengelolaan perikanan sehingga tidak muncul konflik kepentingan ataupun benturan kebijakan (Budiarto 2015). Sinergisitas antar lembaga terkait dengan pengelolaan perikanan di daerah sendangbiru sudah berjalan dengan baik dan saling mendukung. Lembaga-lembaga terkait dalam pengelolaan perikanan di daerah Sendangbiru meliputi TNI AL, Polisi Air, PSDKP dan pihak Pelabuhan Pondokdadap.

Nilai skor indikator kapasitas pemangku kepentingan adalah 3. Hal ini menunjukan bahwa kapasitas pemangku kepentingan ada dan difungsikan (keahlian yang didapat sesuai dengan fungsi pekerjaannya. Pemangku kepentingan dapat berasal dari birokrasi pemerintah, swasta, masyarakat, perguruan tinggi, LSM, dan organisasi masyarakat. Peningkatan kapasitas pemangku kepentingan yang ada di daerah Sendangbiru sudah banyak dilakukan sesuai dengan fungsi pekerjaannya. Contohnya untuk pegawai pelabuhan Pondokdadap. Hampir seluruh pegawai disana pernah mengikuti pelatihan-pelatihan dan seminar terkait bidang kompetensi mereka. Untuk masyarakat dan organisasi masyarakat juga banyak dilakukan sosialisasi dan pembinaan terkait dengan pengelolaan perikanan yang bertanggung jawab oleh Dinas Kelautan dan Perikanan Kabupaten, LSM maupun pihak perguruan tinggi.

\section{Status Pengelolaan Perikanan Tuna}

Hasil analisis komposit antar domain terhadap status dari setiap dari setiap domain dalam EAFM diperoleh nilai rata-rata berkisar antara 63.33-100, mulai dari kategori sedang hingga kategori sangat baik. Hasil analisis komposit setiap domain/aspek selengkapnya dapat dilihat pada Tabel 10. Rata-rata nilai komposit domain sumberdaya ikan adalah yang paling rendah (63.33) dengan kategori sedang, hal ini disebabkan karena pengaruh penilaian terhadap indikator CPUE yang berada pada kondisi buruk. Buruknya kondisi tersebut diakibatkapenurunan CPUE yang sangat besar yakni sebesar $43 \%$ pada tahun 2014. Penurunan CPUE yang cukup besar juga pernah terjadi pada tahun 2006 yakni sebesar 37\% (Hulaifi 2011). Hal ini tentu menandakan telah terjadinya penurunan stok ikan tuna di daerah perairan Sendangbiru akibat besarnya tekanan terhadap perikanan tuna di wilayah tersebut. Bila hal ini cenderung dibiarkan bukan tidak mungkin kategori sedang pada kondisi domain/aspek sumberdaya ikan akan berubah menjadi buruk dalam beberapa tahun mendatang.

Kondisi aspek habitat dan ekosisem perairan berada pada tingkat sedang dengan nilai 71.67. Kondisi ini dipengaruhi oleh penilaian terhadap indikator ekosistemlamun dan ekosistem mangrove dan mempengaruhi nilai komposit dari domain/aspek habitat dan ekosistem perairan. Dari hasil wawancara terhadap nelayan Sendangbiru ekosistem lamun tidak pernah dijumpai oleh warga dan nelayan sekitar. Hal ini dapat juga dijadikan saran untuk penilaian indikator status ekosistem lamun agar dapat dihilangkan bagi daerah yang benar-benar tidak ada ekosistem lamunnya sehingga tidak mempengaruhi penilaian keseluruhan terhadap domain/aspek habitat dan ekosistem perairan. Pengelolaan 
kawasan mangrove juga sangat diperlukan agar luasanya tidak berkurang akibat dari aktivitas masyarakat di Sendangbiru mengingat pentingnya mangrove bagi ekosistem perairan. Penurunan luasan mangrove akan berdampak pada penurunan nilai ekonomi dan tidak dapat mencegah terjadinya abrasi sehingga ruang daratan semakin sempit (Maedar 2007). Ekosistem mangrove juga memiliki peran penting sebagai habitat ikan dan beberapa hewan. Wibowo (2006) juga mengatakan bahwa ekosistem hutan mangrove merupakan ekosistem yang penting untuk mendukung perikanan karena merupakan habitat bagi berbagai ikan dan satwa lainnya. Maka untuk memperbaiki ekosistem mangrove yang ada perlu dilakukan penanaman mangrove secara kontinu selama beberapa tahun mendatang yang harus didukung oleh banyak pihak terkait.

\section{Kondisi domain/aspek teknik penangkapan ikan mendapatkan hasil komposit sangat baik dengan nilai 91.67. Hal ini menandakan bahwa teknik penangkapan ikan tuna yang dilakukan nelayan pancingulur di Sendangbiru sudah sangat ramah lingkungan. Penggunaan alat tangkap (pancing ulur) dan metode penangkapan yang dipakai oleh nelayan bersifat ramah lingkungan. Pancing ulur merupakan salah satu alat penangkapan ikan yang dikategorikan sebagai alat tangkap yang ramah lingkungan (Monintja 1997). Untuk selektivitas hasil tangkapan juga menunjukan bahwa hasil tangkapan yang diperoleh sebagian besar sudah layak tangkap.}

Secara ekonomi, kegiatan perikanan tuna yang ada di daerah Sendangbiru sudah dapat memberikanan penghasilan yang layak (diatas UMK yang sudah ditetapkan) bagi nelayan. Dengan penghasilan yang didapat, banyak nelayan tuna yang mampu menambah kepemilikan asetnya. Kondisi dari aspek ekonomi mendapatkan hasil yang sangat baik dengan nilai 100 . Kegiatan operasi penangkapan ikan tuna yang dilakukan oleh unit perikanan pancing ulur di Sendnagbiru dinilai menguntungkan dan secara finansial juga layak untuk dilanjutkan (Rahma 2013). Keuntungan yang cukup besar pada usaha perikanan tuna dengan menggunakan pancing ulur menjadi daya tarik sendiri bagi nelayannelayan yang ada. Hal ini juga dapat menyebabkan semakin tingginya tekanan terhadap sumberdaya tuna itu sendiri.

Dari segi aspek sosial, kondisinya sedang dengan nilai 71.67. Penilaian terhadap indikator pemanfaatan pengetahuan lokal dalam pengelolaan sumberdaya ikan mempengaruhi penilaiankeseluruhan terhadap aspek sosial. Pengetahuan tentang penangkapan ikan tuna hinggu lebih dari 180 mil kebanyak dibawa oleh nelayan pendatang dari daerah Sulawesi. Penggunaan rumpon sebagai alat bantu juga dikenalkan oleh nelayan pendatang. Pengelolaan perikanan tuna di daerah sendangbiru kedepannya diharapkan dapat memasukan unsur-unsur kearifan lokal sebagai salat satu landasannya yang disetujui oleh seluruh pemangku kepentingan.

Kondisi dari domain/aspek kelembagaan berada pada kondisi sangat baik dengan nilai 83.33. kondisi ini masih perlu dilakukan perbaikan lagi terhadap indikator kepatuhan terhadap prinsip-prinsip perikanan yang bertanggung jawab. Diperlukan suatu penindakan secara tegas terkait pelanggaranpelanggaran yang dilakukan. Aspek kelembagaan yang dinilai dalam EAFM lebih mengarah kepada penilaian terhadap instansi pemerintah. Penilaian juga seharusnya dilakukan terhadap lembaga-lembaga atau organisasi nelayan yang ada untuk melihat apakah organisasi yang diikuti memberikan dampak positif bagi nelayan. Secara keseluruhan tingkat keberlanjutan perikanan tuna di daerah Sendangbiru diperoleh hasil baik dengan nilai 80.28 dari analisis komposit dari setiap domain yang ada dengan pendekatan ekosistem (Tabel 10).

\section{KESIMPULAN}

Domain/aspek yang memiliki tingkat keberlanjutan sangat baik meliputiaspek teknik penangkapan ikan, ekonomi dan kelembagaan, sedangkan domain/aspek yang memiliki tingkat keberlanjutan sedang meliputi sumberdaya ikan, habitat dan ekosistem perairan dan sosial. Tingkat keberlanjutan kegiatan perikanan tuna di daerah Sendangbiru 
tergolong baik dengan perolehan nilai dari analisis komposit dari setiap domain/aspek dalam EAFM sebesar 80.28.

\section{DAFTAR PUSTAKA}

Andamari R, Hutapea JH, Prisanto BI. 2012. Aspek Reproduksi Ikan Tuna Sirip Kuning (Thunun albacares). Jurnal Ilmu dan Teknologi Kelautan Tropis. 4(1):89-96.

Budiarto A. 2015. Pengelolaan Perikanan Rajungan dengan Pendekatan Ekosistem di Perairan Laut Jawa (WPPNRI 712). [thesis]. Bogor (ID): IPB

Charles, Anthony T. 2001. Sustainable fishery system. Blackwell Scientific Publication. Oxford. UK.

FAO. 2003. Ecosystem Approach to Fisheries. FAO Technical paper.

Hulaifi. 2011. PendugaanPotensi Sumberdaya Perikanan LAut dan Tingkat Keragaan Ekonomi Penangkapan Ikan (Kasus di TPI Sendanbiru Kabupaten Malang). Jurnal Matematika, Sains, dan Teknologi. 12(2): 113-126

Katun W, Amir F. 2013. Struktur Umur, Pola Pertumbuhan dan Mortalitas Tuna Madidihang Thunnus albacores (Bonnatere, 1788) di Selat Makasar. Jurnal Balik Diwa. 4(1): 8-14

Luthfi OM, Putri P, Kirana FS, Wahyudiarto A, Fakri SR, Sofyan M, Faruk R, Ghofur MA, Murian S, Tovani I. 2016. Biodiversitas dan Populasi Ikan Karang di Perairan Selat Sempu Sendangbiru Kabupaten Malang Jawa Timur. Jurnal Kelautan. 9(1): 43-49.

Luthfi OM, Novita M, Alfan J. 2015. Growth Rate of Staghorn Coral (Acropora) on Coral Garden Program at Sempu Nature Reserve Malang. Reaserch Journal of Life Science. 2(2).

Maedar F. 2007. Analisis Ekonomi Ekosistem Mangrove Di Kecamatan Merawang Kabupaten Bangka. Proceeding Geo-Marine Reaserch Forum. Hal 93-107.

Mahmudi M. 2003. Studi Kondisi Ekosistem Terumbu Karang Serta Strategi Pengelolaannya (Studi Kasus di Teluk Semut Sendangbiru Malang. Pengantar Falsafah Sains. Bogor (ID): IPB.

Monintja DR. 1997. Agribisnis Penangkapan Ikan. Bahan Pelatihan Analisis Investasi Agribisnis Bidang Penangkapan Ikan. Bank BNI-LPSDM IPB. 24 hal.

Nurani TW, Haluan J, Sudirman S, Lubis E. 2008. Rekayasa Sistem Pengembangan Perikanan Tuna di Perairan Selatan Jawa. Forum Pascasarjana. 31(2): 79-92.

Pillai NG dan Satheeshkumar P. 2012. Biology, Fishery, Conservation and Management of Indian Ocean Tuna Fisheries. Ocean Science Journal. 47(4): 411-433.

Pradana AO. 2011. Pemetaan Hutan Mangrove dengan Citra Satelit LANSAT dan Persepsi Masyarakat dalam Upaya Pelestarian Mangrove di Kecamatan Sumbermanjing Wetan Kabupaten Malang. [thesis]. Malang (ID): Universitas Brawijaya.

Ross A, Wiyono ES, Nurani TW. 2012. Persepsi Sosial Stakeholder Perikanan Tangkap di PPN Prigi, Trenggalek. Buletin PSP. 20(3): 229-237.

Salganik MJ, Douglas DH. 2007. Sampling and Estimation in Hiden Populations Using Respondent Driven Sampling. Journal Sociological Methodology, 34(1).

Sumadhiharga OK. 2009. Ikan Tuna. Pusat Penelitian Oceanografi. Lembaga Ilmu Pengetahuan Indonesia. Jakarta. Hal 1-34.

Wibowo K, Handayani T. 2006. Pelestarian Hutan Mangrove Melalui Pendekatan Mina Hutan (SILVOFISHERY). Jurnal Teknologi Lingkungan PTL-BPPT. 7(3):227-223. 